\title{
CARTA A LOS SOCIOS DE ÁNGEL SANCHO ÁLVAREZ
}

\section{Letter to the members of Angel Sancho Alvarez}

\author{
Ángel SANCHO-ÁLVAREZ \\ Presidente de Honor de la Sociedad Otorrinolaringológica de Castilla y León, Cantabria y La Rioja. España \\ Correspondencia: rsancho61@hotmail.com
}

Fecha de publicación: 17 de junio de 2019

Fecha de publicación del fascículo: 1 de septiembre de 2019

Conflicto de intereses: Los autores declaran no tener conflictos de intereses

Imágenes: Los autores declaran haber obtenido las imágenes con el permiso de los pacientes

Política de derechos y autoarchivo: se permite el autoarchivo de la versión post-print (SHERPA/RoMEO)

Licencia CC BY-NC-ND. Licencia Creative Commons Atribución-NoComercial-SinDerivar 4.0 Internacional

Universidad de Salamanca. Su comercialización está sujeta al permiso del editor

Estimados socios:

Valladolid, 10 de junio de 2019

En la asamblea de nuestra Sociedad, celebrada el 1 de junio en el XXVII Congreso en Soria, se aprobó el cambio de la denominación de los premios que se conceden en cada congreso. En el próximo congreso y sucesivos llevarán mi nombre.

Ante esta decisión me siento enormemente orgulloso y agradecido. Muchas gracias a la Junta Directiva y a todos los socios. Sabéis cuánto amo a nuestra Sociedad, a la que he tenido el honor de dirigir durante quince años.

Muchas gracias a todos: 